Idarotuna, Vol. 1. No. 1. Oktober 2018

\title{
MODEL KOMUNIKASI DAKWAH MAJELIS DAKWAH ISLAMIYAH (MDI) KOTA PEKANBARU
}

\author{
Khairuddin dan Bobi Candra \\ Fakultas Dakwah dan Komunikasi UIN Suska Riau \\ Email: khairuddin@uin-suska.ac.id
}

\begin{abstract}
Abstrak
Kota Pekanbaru memasuki era perkembangan diberbagai bidang, baik teknologi, pendidikan dan kultur masyarakat yang berdampak pada perubahan. Salah satu perubahan yang terjadi yaitu pesatnya perkembangan dakwah di Kota Pekanbaru. Majelis Dakwah Islamiyah (MDI) Kota Pekanbaru sebagai lembaga dakwah harus mampu melahirkan model komunikasi yang efektif dalam proses penyampaian dakwah sesuai dengan kondisi masyarakat saat ini. Permasalahan pada penelitian ini adalah bagaimana model komunikasi dakwah Majelis Dakwah Islamiyah (MDI) Kota Pekanbaru. Tujuannya untuk mencari tahu model komunikasi dakwah yang digunakan oleh MDI kota Pekanbaru. Subjek penelitian ini adalah pengurus Majelis Dakwah Islamiyah (MDI) Kota Pekanbaru sedangkan objeknya adalah model komunikasi dakwahnya. Penelitian ini disusun dengan kerangka pikir yang sistematis menggunakan model deduktif. Jenis penelitian ini adalah deskriptif dan menggunakan pendekatan kualitatif. Informan penelitian berjumlah 5(lima) orang. Pengumpulan data dilakukan melalui observasi, wawancara, dan dokumentasi dan hasil data tersebut dianalisis secara deskriptif kualitatif. Dari hasil penelitian ditemukan bahwa model komunikasi dakwah Majelis Dakwah Isamiyah (MDI) Kota Pekanbaru dilakukan dengan dua cara, yaitu; model komunikasi dakwah tradisional dan modern. Model komunikasi dakwah tradisional dilakukan secara langsung oleh da'i kepada mad'u dalam bentuk halaqah, muhasabah, diskusi ilmiah dan seminar, khutbah jum'at dan majelis taklim. Model komunikasi dakwah modern dilakukan oleh da'i secara tidak langsung kepada mad'u melalui televisi, radio, media massa, dan media cetak.
\end{abstract}

Keyword: Model, Komunikasi Dakwah, Majelis Dakwah Islamiyah. 


\section{Pendahuluan}

Komunikasi merupakan sebuah aktivitas dasar manusia untuk berinteraksi dengan lainnya. Tidak ada manusia yang tidak akan terlibat dalam komunikasi. Dalam al-Qur'an terdapat banyak sekali ayat yang menggambarkan tentang proses komunikasi. Salah satu diantaranya adalah dialog yang pertama kali antara Allah SWT dan Malaikat yang membicarakan tentang penciptaan manusia. ${ }^{1}$ Pentingnya komunikasi bagi manusia tidak dapat dipungkiri. Dengan adanya komunikasi yang baik, aktivitas manusia dapat berjalan dengan lancar.

Komunikasi dari segi bahasa berasal dari kata "Communicare" yang bermakna penyampaian atau pemberitahuan yang dilakukan baik secara perorangan (individu) atau kelompok yang ingin mempengaruhi orang lain. Hal ini sejalan dengantujuan dakwah yang sebenarnya yaitu berusaha mempengaruhi orang lain ke arah yang lebih baik. Keberhasilan dakwah salah satunya bergantung pada cara berkomunikasi Da'i kepada jama'ahnya. Hal ini dibuktikan dengan keberhasilan dakwah yang dilakukan Rasulullah SAW dalam memperjuangkan Islam melalui penggunaan komunikasi yang efektif menyentuh lubuk hati dan pikiran manusia. Bahkan, Rasulullah SAW sangat piawai dalam merangkai pesan-pesan yang akan disampaikan, baik dalam bentuk khutbah, atau dalam berkomunikasi seharihari.

Tidak diragukan lagi keberhasilan dakwah jika para Da'i dapat menerapkan model komunikasi dakwah yang pernah dilakukan oleh Rasulullah Saw. Keberhasilan dakwah yang sangat tergantung pada kemampuan kita mengkomunikasikan ajaran agama yang kita yakini kebenarannya. Disini kita

\footnotetext{
${ }^{1}$ Penjelasan ini selaras dengan isi (al-Qur'an Surah al-baqarah: 30)

${ }^{2}$ Abd Rohman, Komunikasi dalam AlQur'an ( Realisasi Ilahiyah dan Insaniah ), (Malang: UIN- Malang Press, 2007), hlm. 2
}

dituntut memahami komunikasi yang baik yang dapat mendukung tugas yang mulia tersebut.

Dalam mengembangkan dakwah, MDI kota Pekanbaru menerapkan model komunikasi dakwah yang khas sehingga eksistensi para Da'i nya cukup dikenal oleh masyarakat. Kota Pekanbaru yang telah memasuki masa modernisasi yang menjadi objek utamanya yaitu umat Islam. Saat ini umat Islam mendapatkan serangan modernitas terhadap komunitas Islam itu sendiri. Kemajuan teknologi dan informasi membawa dampak yang sangat memprihatinkan bagi umat Islam saat ini. Semakin berkembang suatu peradaban maka akan semakin maju pola pikirnya. Jika perkembangan tersebut kearah yang lebih baik tidak menjadi masalah, namun yang menjadi tugas pokok ialah jika perkembangan tersebut kearah yang tidak baik.

Dari interpretasi di atas merupakan tantangan yang sangat serius bagi MDI Kota Pekanbaru. Hal ini bukanlah penghambat yang akan menghentikan lajunya dakwah yang disebarkan oleh MDI Kota Pekanbaru. Sebagai bukti nyata yaitu sampai saat ini bisa dilihat MDI Kota Pekanbaru tidak pernah padam dalam menyampaikan syiar Islam. Tentunya sebagai kaum intelektual yang menitik beratkan keilmuan di bidang dakwah akan bertanya-tanya, mengapa MDI Kota Pekanbaru tetap eksis dalam menyampaikan dakwah sampai saat ini?. Jenis penelitian ini adalah deskriptif kualitatif. Metode ini memaparkan situasi atau peristiwa tanpa mencari atau menjelaskan hubungan antara variabel dan tidak melakukan pengujian hipotesis dan membuat prediksi. ${ }^{3}$

\section{Pengertian Komunikasi Dakwah}

Komunikasi dakwah adalah suatu retorika (persuasif) yang dilakukan oleh komunikator dakwah (Da'i) untuk

3 Tim Penyusun Fakultas Dakwah dan Komunikasi Universitas Islam Negeri Sultan Syarif Kasim Riau-Pekanbaru, 2010: 34 
menyebarluaskan pesan-pesan bermuatan nilai agama, baik dalam bentuk verbal maupun nonverbal kepada jama'ah untuk memperoleh kabaikan di dunia dan di akhirat. ${ }^{4}$ Komunikasi dakwah menurut Toto Tasmara adalah suatu bentuk komunikasi yang khas dimana seorang komunikator menyampaikan pesan-pesan yang bersumber atau sesuai dengan ajaran Al-Qur'an dan Sunnah, dengan tujuan agar orang lain dapat berbuat amal shaleh sesuai dengan pesan-pesan yang disampaikan. ${ }^{5}$

\section{a. Model Komunikasi Dakwah}

Komunikasi dakwah merupakan proses penyampaian pesan ajaran agama Islam kepada masyarakat agar memiliki pemahaman dan prilaku yang islami. ${ }^{6}$ Dalam proses komunikasi, pesan dakwah harus dikemas secara menarik. Model komunikasi dakwah menunjukkan suatu dalam sistem dakwah karena pola komunikasi menyediakan konteks atau ruang untuk memahami tingkah laku yang spesifik. $^{7}$ Ada 3 (tiga) faktor pembentuk model komunikasi dakwah seseorang, yaitu: pertama, proses sejarah atau pengalaman masa lalu yang kemudian membentuk kebiasaan yang menjadi bagian dari kepribadian; kedua, kapasitas sebagai akibat dari factor pendidikan, pelatihan serta pengalaman hidup diri seseorang dalam menempuh kehidupan; ketiga, maksud dan tujuan dari aktivitas komunikasi sehingga membawa kepada penyesuaian pesan, metode, dan media yang dipergunakan.

Dalam pembagiannya, model komunikasi dakwah sebuah lembaga dibagi menjadi dua bagian yaitu:

\section{1) Model Komunikasi Dakwah Tradisional}

4 Bambang S. Ma'arif, Komunikasi Dakwah; Paradigma Untuk Aksi, (Bandung: Simbiosa Rekatama Media, 2010), hlm. 34.

5 Toto Tasmara, Komunikasi Dakwah, (Jakarta: Gaya Meda Pratama, 1997), cet-2, hlm. 49

6 Toni Hartono,Komunikasi Dakwah, hlm. 122.

${ }^{7}$ Bambang S. Ma'arif, Komunikasi Dakwah; Paradigma Untuk Aksi,hlm.78.
Sebagai sebuah kenyataan dan fenomena dakwah yang berkembang dikalangan masyarakat Indonesia saat ini terutama bagi masyarakat awam terdapat beberapa model dan konsep dakwah yang dikembangkan oleh para ulama. Model komunikasi dakwah tradisional ini terbagi menjadi dua yaitu:

\section{a) Tarekat}

Dari segi bahasa tarekat berasal dari bahasa Arab Thariqoh yang artinya jalan, keadaan, aliran dalam garis sesuatu. ${ }^{8}$ Menurut Harun Nasution ${ }^{9}$ tarekat adalah jalan yang harus ditempuh seorang sufi dalam tujuan berada sedekat mungkin dengan Tuhan secara rohaniyah. Tarekat juga diartikan sekumpulan cara-cara yang bersifat renungan dan usaha inderawi yang mengantarkan pada hakikat, atau suatu data yang benar. ${ }^{10}$ Tarekat dalam bahasan komunikasi dakwah merupakan bagian yang penting untuk dikembangkan lebih lanjut karena merupakan bagian dari misi dakwah Islam yang mengajarkan kebaikan dan kebenaran yang berdasarkan al-Qur'an dan Sunnah. ${ }^{11}$

\section{b) Tabligh}

Tabligh adalah usaha menyampaikan dan mensyiarkan agama Islam yang dilakukan secara individu maupun kelompok baik secara lisan maupun tulisan. ${ }^{12}$ Menurut Khadijah tabligh adalah berdakwah dengan menyampaikan

8 Abuddin Nata dalam Toni hartono, Komunikasi Dakwah, 125.

${ }^{9}$ Azyumardi Azra, Menuju Masyarakat Madani: Gagasan, Fakta, dan Tantangan, (Bandung: Rosdakarya, 2000), hlm. 37.

${ }^{10}$ Ibid,hlm. 37. hlm. 127.

${ }^{11}$ Toni Hartono dkk. Komunikasi Dakwah,

12 Moh. Ali Aziz, Ilmu Dakwah, (Jakarta: Kencana, 2008), hlm. 21. 
tuntunan untuk melaksanakan suatu ibadah. $^{13}$

\section{2) Model Komunikasi Dakwah Modern}

Media massa yang digunakan merupakan hasil perkembangan ilmu pengetahuan dan teknologi sebagai bentuk penguasaan manusia terhadap sunnatullah yang menguasai alam. Media massa sebagai alat atau saluran dalam menyampaikan dakwah dapat diartikan sebagai proses komunikasi yang dilakukan melalui media massa dengan berbagai tujuan komunikasi dan untuk menyampaikan informasi kepada khalayak luas. Proses komunikasi massa tersebut terlihat berproses dalam bentuk:

1) Melakukan distribusi dan penerimaan informasi dalam skala besar. Jadi proses komunikasi massa melakukan distribusi informasi kemasyarakatan dalam skala besar. Satu kali siaran pemberitaan yang disebarkan dalam jumlah yang luas dan diterima oleh massa yang besar pula.

2) Proses komunikasi massa juga dilakukan melalui satu arah yaitu komunikator dakwah kepada khalayak pendengar sebagai jama'ah. Jika terjadi interaktif di antara mereka maka proses komunikasi yang disampaikan oleh komunikan ke komunikator sifatnya sangat terbatas sehingga tetap saja didominasi oleh komunikator.

3) Proses komunikasi massa terjadi secara asimetris, menyebabkan komunikasi di antara mereka berlangsung datar dan bersifat sementara. Kalau terjadi kondisi emosional disebabkan karena pemberitaan yang sangat agitatif maka sifatnya sementara tidak

\footnotetext{
${ }^{13}$ Alwisral Imam Zaidallah, Strategi Dakwah dalam membentuk Da'i dan Khotib Professional, (jakarta: Kalam Mulia, 2005), hlm. 110.
}

berlangsung lama dan tidak permanen.

4) Proses komunikasi dakwah juga berlangsung impersonal dan tanpa nama. Proses menjamin bahwa komunikasi massa akan sulit diidentifikasi siapa penggerak dan menjadi motor dalam sebuah gerakan massa di jalan.

5) Proses komunikasi massa juga berlangsung berdasarkan pada hubungan-hubungan kebutuhan di masyarakat.

Beberapa Media yang dapat mendukung Komunikasi Dakwah, antara lain:

\section{a. Dakwah melalui Televisi}

Sebagai media komunikasi massa, televisi memiliki ciri-ciri diantaranya bersifat satu arah serta terbuka untuk publik secara luas dan tidak terbatas. Dalam sejarah perkembangannya pada tahun 1992 di Indonesia telah berkembang $\mathrm{PH}$ (Production House) lebih kurang 300 buah. $^{14}$ Hal ini menandakan bahwa perkembangan dunia pertelevisian di Indonesia semakin meningkat dan membuktikan bahwa kalangan masyarakat Indonesia sangat antusias terhadap tayangantayangan yang dimuat oleh $\mathrm{PH}$ masing-masing sehingga pesanpesan komunikasi dakwah dapat mewarnai setiap sisi kehidupan masyarakat Indonesia. ${ }^{15}$

\section{b. Dakwah melalui Radio}

sebagai media penyampaian informasi ataupun sarana khutbah yang bersifat Islami. Walaupun banyak media yang berkembang pesat saat ini, namun media radio mampu bertahan sampai sekarang

\footnotetext{
${ }^{14}$ Asep Muhyiddin dan Agus Ahmad Syafei, Metode Pengembangan Dakwah,(Bandung: Pustaka Setia, 2002)hlm.204.

${ }^{15}$ Toni Hartono dkk. Komunikasi Dakwah, hlm. 135 .
} 
dan masih banyak penggunanya. ${ }^{16}$ Tiga alasan mengapa radio semakin dilirik, karena sifat ketersegeraan (actuality), berita radio yang tersaji secara langsung menjadi primadona karena aktualitas dan objektivitasnya terjamin tanpa rekayasa ulang dari redaktur. Sifat format kemasan (bodystyle), kemasan berita radio dewasa ini makin bervariasi sehingga memudahkan pendengar (audien) untuk memilih kemasan yang pas buat mereka, dan mencatat waktu penyiaran yang sesuai dengan kesibukan mereka. Sifat lokalitasnya sebagai sarana komunikasi publik, radio menganut prinsip segmentasi menurut kedekatan geografis dan prilaku sosial masyarakat sekitarnya.

Prinsip ini mengharuskan radio bersifat sangat lokal, radio lebih mampu menyerap aspirasi lokal dan menyiarkannya. Kehadiran radio sebagai media dakwah adalah sudah lama dimanfaatkan. Hanya saja bagaimana mengemas dakwah melalui media radio agar lebih efektif masih perlu dikaji lebih dalam oleh pengelola radio dan lembaga-lembaga dakwah. Terkait dengan efektifitas tersebut maka ada hal yang paling mendasar yang perlu dikaji yakni berkaitan dengan format program siaran dakwah Islam. Tidak kalah pentingnya adalah mengenai keterbatasan waktu yang disediakan untuk program siaran dakwah Islam di radio yang relatif sedikit. ${ }^{17}$

\section{c. Dakwah melalui Internet}

Internet adalah sistem jaringan komputer yang terhubung ke seluruh dunia, dapat disebut

${ }^{16}$ Dokumentasi "Dakwah Melalui Radio" http://fenditungkal.blogspot.com/2009/11/dakwahislam-melalui-radio.html (diakses 08 Desember 2015 pukul 06.44 WIB).

\section{Dakwah"}

${ }^{17}$ Dokumentasi "Radio Sebagai Media

http://www.islamcendikia.com/204/01/radiosebagai-media-dakwah.html? $\mathrm{m}=1$ (diakses pada 08 Desember 2015, pukul 06.48). sebagai kolaborasi teknis antara komputer yang memiliki jaringan interkoneksi. Penggunaan internet dalam berdakwah telah dimungkinkan, sangat urgen, dan sangat strategis dalam masyarakat informasi. Internet telah mengubah komunikasi dengan cara yang mendasar, terutama melibatkan interaktivitas antara komunikator dengan pengguna. Melalui internet kegiatan dakwah dapat terlaksana dengan menyertakan jutaan orang di seluruh dunia, tanpa adanya hubungan yang bersifat pribadi. Jika internet digunakan untuk dakwah, maka penerima dakwah yang dapat tercipta oleh internet tersebut sangat khas, yaitu jutaan individu yang terhubung oleh jaringan komputer, disebut dengan dunia maya. ${ }^{18}$

Dakwah melalui jaringan internet dinilai sangat efektif dan potensial dengan berbagai alasan di antaranya: pertama, mampu menembus batas ruang dan waktu dalam sekejap dengan biaya dan energi yang relatif dan terjangkau; kedua, pengguna jasa internet setiap tahunnya meningkat drastis, ini berarti berpengaruh pada jumlah penyerap misi dakwah; Ketiga, para pakar dan ulama yang berada dibalik media dakwah via internet bisa lebih konsentrasi dalam menyikapi setiap wacana dan peristiwa yang menuntut status hukum syar'i; Keempat, dakwah melalui internet telah menjadi salah satu pilihan masyarakat.

Internet memiliki tiga keunggulan. Pertama, karena sifatnya yang never turn-off (tidak pernah dimatikan) dan unlimited acces (dapat akses tanpa batas). Internet memberikan keleluasaan kepada penggunanya untuk

18 Anwar Arifin, Dakwah Kontemporer: Sebuah Studi Komunikasi, 92. 
mengakses dalam kondisi dan situasi apapun; Kedua, internet merupakan tempat yang tepat bagi mereka yang ingin berdiskusi tentang pengalaman spiritual yang mungkin tidak rasional dan bila dibawa pada forum yang biasa akan mengurangi keterbukaannya. Para saintis biasanya merasa terbatasi oleh koridor ilmiah untuk mengekspresikan suatu pikiran atau pengalaman. Internet menyediakan ruang yang mengakomodasi keinginan mereka untuk merasa bebas membicarakan sesuatu yang diluar kelaziman ilmiah; Ketiga, sebagian orang yang memiliki keterbatasan dalam komunikasi sering kali mendapat kesulitan guna mengatasi dahaga spiritual mereka. Padahal mereka ingin sekali berdiskusi dan dapat mendapat bimbingan dari para ulama. Sementara itu ada sebagian orang yang ingin bertanya atau siap berdebat dengan para ulama untuk mencari kebenaran namun kondisi tidak memungkinkan. Internet hadir sebagai kawan (atau lawan) diskusi sekaligus pembimbing setia. Para ulama seharusnya dapat menggunakan internet sebagai media efektif untuk mencapai tujuan dakwahnya. ${ }^{19}$

\section{d. Dakwah melalui Media Cetak}

Saat ini surat kabar dan majalah telah berkembang menjadi media dengan kemampuan yang tak terbatas oleh wilayah bangsa dan negara. Kemajuan teknologi cetak yang sangat canggih menyebabkan hasil cetakan berwarna menyeruai aslinya, bahkan melebihinya. Dengan kemajuan teknologi saat ini, pesan dakwah dapat dilakukan secara berkala dan continue sehingga diharapkan audiens yang menjadi

19 Toni Hartono dkk. Komunikasi Dakwah, 141. pembacanya dapat terpengaruh dan berubah menjadi lebih baik. Sebagai media transmisi, surat kabar atau majalah relatif dapat mentransmisikan informasi dan sumber berita ke khalayak dalam waktu yang tepat.

Dari seluruh media massa yang menjadi saluran dakwah kontemporer di Indonesia pada khususnya dalam kapasitasnya sebagai media komunikasi atau media dakwah memiliki keunggulan dan kelemahan masing-masing. Para Da'i sebagai komunikator dakwah dapat memilah dan memilih jenis media massa untuk digunakan sebagai media dakwah dalam menyampaikan pesan kepada khalayak dan masyarakat. Penetapan media massa yang akan digunakan sebagai media dakwah, tentu harus disesuaikan dengan kebijakan masing-masing media massa atau agenda masing-masing media. Karena media massa sebenarnya memiliki agenda tersendiri yakni agenda media yang digunakan sebagai acuan dalam melakukan agenda setting. Kenyataannya di Indonesia memiliki kebijakan yang membuka diri bagi kegiatan yang berkaitan dengan dakwah. Media massa di Indonesia banyak yang membuka rubrik dakwah. Di samping itu, media juga memberikan waktu khusus dalam melakukan dakwah bahkan mensyiarkan secara langsung kegiatan dakwah Islam. ${ }^{20}$

\section{Hasil Penelitian}

\section{Model Komunikasi Dakwah Tradisional \\ Model komunikasi dakwah yang} dilakukan oleh Majelis Dakwah Islamiyah (MDI) Kota Pekanbaru yang berwajahkan tradisional adalah wujud keseriusan Majelis Dakwah Islamiyah

\footnotetext{
${ }^{20}$ Toni Hartono dkk. Komunikasi Dakwah
} 143. 
(MDI) Kota Pekanbaru yang tetap merujuk kepada pola dakwah Rasulullah SAW secara umum. Kegiatan dakwah tradisional ini lebih kepada komunikasi sehari-hari yang sejak dahulu juga telah terealisasikan. Diantara model dakwah yang digunakan oleh MDI yaitu:

\section{a. Dakwah melalui Halaqah}

Kegiatan dakwah dalam bentuk Halaqah dilakukan oleh Majelis Dakwah Islamiyah (MDI) Kota Pekanbaru sebagai rutinitas mingguan secara intern dan terkadang dilakukan dengan jadwal tertentu dalam bentuk ekstern. Dalam analisis penulis kegiatan Halaqah yang dilakukan Majelis Dakwah Islamiyah (MDI) Kota Pekanbaru merupakan gebrakan dakwah yang sangat fundamental dalam mengantisipasi perbedaan pemahaman oleh para $\mathrm{Da}^{\prime} i$ nya. Majelis Dakwah Islamiyah (MDI) Kota Pekanbaru mengadakan kegiatan Halaqah yang diperuntukkan kepada para Da'i nya dengan maksud agar materi dakwah yang telah ditetapkan oleh Majelis Dakwah Islamiyah (MDI) Kota Pekanbaru dapat mereka pahami dalam sudut pandang yang sama tanpa adanya perbedaan asumsi. Kegiatan rutin setiap Jum'at pagi ini merupakan langkah positif yang dilakukan Majelis Dakwah Islamiyah (MDI) Kota Pekanbaru untuk memberikan ultimatum penting kepada para Da'i agar saat mereka berdakwah dengan menggunakan "attribute" atas nama Majelis Dakwah Islamiyah (MDI) Kota Pekanbaru, maka pemahaman yang sama terhadap syari'at harus dijunjung tinggi tanpa mengedepankan "ego" terhadap mazhab yang diyakini.

Lebih jauh daripada itu, dalam pemahaman penulis kegiatan Halaqah ini menjadikan Majelis
Dakwah Islamiyah (MDI) Kota Pekanbaru sebagai salah satu lembaga dakwah yang mampu merancang strategi dan me-manage dakwahnya dalam tatanan yang baik. Rutinitas Halaqah setiap hari Jum'at ini juga dapat membuat jama'ah tidak perlu resah dengan persoalan "khilafiyah" yang saat ini mulai mencuat lagi ke permukaan. Dalam kegiatan Halaqah, setiap Da'i telah dibekali dengan pemahaman yang sama terhadap materi yang disampaikan dan ditekankan dengan tegas agar menjauhi segala penyampaian yang bersinggungan dengan permasalahan "khilafiyah" yang dikhawatirkan akan membuat jama'ah tumpang tindih dalam menerima pesan dakwah atau mungkin dapat terjadi kesalahpahaman antara apa yang disampaikan oleh $\mathrm{Da}^{\prime} i$ yang satu dengan Da'i lainnya.

Dalam kesempatan lain pun, Da'i Majelis Dakwah Islamiyah (MDI) Kota Pekanbaru juga melakukan kegiatan Halaqah bersama beberapa jama'ah kecil dengan jadwal tertentu yang membahas beberapa materi ringan sebagai bentuk selingan dari kegiatan dakwah lainnya. Pada akhirnya semua tindakan itu merupakan implementasi dari model komunikasi dakwah tradisional dalam bentuk Halaqah yang telah terlaksana dengan baik oleh Majelis Dakwah Islamiyah (MDI) Kota Pekanbaru.

\section{b. Dakwah melalui Muhasabah}

Dalam bentuk Muhasabah yang dilakukan oleh Majelis Dakwah Islamiyah (MDI) Kota Pekanbaru para Da'i juga memiliki peran besar di dalam pelaksanaannya.Kegiatan Muhasabah sendiri memang bukan program tetap di Majelis Dakwah Islamiyah (MDI) Kota Pekanbaru. Akan tetapi kegiatan Muhasabah ini cukup sering dilakukan dalam peringatan Hari Besar Islam (HBI) 
maupun menjelang masuknya bulan suci Ramadhan. Kegiatan Muhasabah yang dilaksanakan secara umum terbagai menjadi dua, yakni Muhasabah yang memang digagas oleh Majelis Dakwah Islamiyah (MDI) Kota Pekanbaru sendiri yang diperuntukkan bagi para Da'i nya dan juga kegiatan Muhasabah yang merupakan permintaan langsung oleh masyarakat dengan mengundang beberapa Da'i dari Majelis Dakwah Islamiyah (MDI) Kota Pekanbaru. Kedua bentuk pelaksanaan Muhasabah tersebut penulis pahami sebagai bentuk dakwah yang baik dalam menunjang kesuksesan misi dakwah secara universal.

Kegiatan Muhasabah tidak dapat dilakukan oleh setiap Da'i tanpa memiliki kemampuan (skill) khusus, sebab kegiatan Muhasabah ini berbeda dengan penyampaian dakwah di atas mimbar atau pun kegiatan ceramah lainnya. Dalam analisis penulis, Majelis Dakwah Islamiyah (MDI) Kota Pekanbaru telah memberikan prioritas penting dalam menetapkan Da'i-Da'i yang berkompeten terhadap kegiatan Muhasabah ini.

\section{c. Dakwah melalui Diskusi Ilmiah dan Seminar.}

Kegiatan dakwah melalui diskusi ilmiah dan seminar-seminar keagamaan merupakan pelaksanaan dakwah yang benar-benar sesuai dengan keadaan zaman. Pada saat ini dakwah juga harus dikemas dalam tatanan forum yang lebih berkelas dan memiliki intelektualitas. Majelis Dakwah Islamiyah (MDI) Kota Pekanbaru melakukan kegiatan diskusi ilmiah dan seminar ini secara khusus diperuntukkan bagi para Da'i-Da'i nya yang juga bertempat di aula sekretariat Majelis Dakwah Islamiyah (MDI) Kota Pekanbaru.

Lebih lanjut lagi dalam asumsi penulis, Majelis Dakwah Islamiyah (MDI) Kota Pekanbaru untuk mengkaji lebih dalam materi-materi dakwah yang akan disampaikan kepada masyarakat agar para Da'i lebih memahami materi secara tuntas lengkap dengan dalil-dalil dan pendapat para ulama. Hal ini juga dimaksudkan agar para Da'i tidak menyampaikan pesan dakwah berdasarkan penalaran logika dan hawa nafsu yang dikhawatirkan akan menyimpang dari kaidah sebenarnya. Sebuah langkah awal yang baik untuk mengantisipasi segala kemungkinan buruk yang terjadi dalam mewujudkan kesuksesan dakwah.

Perkembangan zaman juga diiringi dengan berbagai fenomena baru dan kasus-kasus terhangat yang menyangkut kepada ajaran agama Islam. Mulai dari aliran-aliran (firqohfirqoh) yang terus berkembang sampai kepada kemajuan teknologi komunikasi yang dapat menghambat kesuksesan dakwah jika tidak dilakukan pencegahan (antisipasi dini). Oleh karena itu kegiatan diskusi ilmiah dan seminar ini penulis pahami sebagai salah satu langkah Majelis Dakwah Islamiyah (MDI) Kota Pekanbaru untuk memberikan pemahaman yang baik bagi para Da'i guna membekali mereka agar selalu up-date dengan perkembangan zaman.

Kegiatan diskusi ilmiah dan seminar keagamaan ini juga seringkali dilakukan di luar lembaga seperti di Masjid-Masjid saat ada jama'ah yang meminta Da'i kompeten dari Majelis Dakwah Islamiyah (MDI) Kota Pekanbaru untuk menjadi narasumbernya. Pelaksanaan diskusi dan seminar ini bukan merupakan program resmi dari Majelis Dakwah Islamiyah (MDI) Kota Pekanbaru, akan tetapi dukungan itu tetap hadir dari Majelis Dakwah Islamiyah (MDI) Kota Pekanbaru sebab kesemua kegiatan itu dapat memberikan manfaat positif bagi kemaslahatan umat.

d. Dakwah melalui Khutbah Jum'at 
Dakwah yang diorientasikan pada kegiatan setiap hari Jum'at merupakan kegiatan rutin yang dilakukan oleh Majelis Dakwah Islamiyah (MDI) Kota Pekanbaru. Penulis memahami bahwa kegiatan dakwah melalui khutbah Jum'at yang dilakukan oleh Majelis Dakwah Islamiyah (MDI) Kota Pekanbaru merupakan sebuah tindakan yang sangat relevan dengan kebutuhan umat. Hal ini terbukti dengan pengorganisasian yang sangat rapi oleh Majelis Dakwah Islamiyah (MDI) Kota Pekanbaru dalam setiap pelaksanaan khutbah Jum'at. Majelis Dakwah Islamiyah (MDI) Kota Pekanbaru menyusun materi-materi yang sangat memperioritaskan aspek kondisional, ditambah lagi dengan penempatan Da'i-Da'i selaku khatib yang sesuai dengan lokasi regional kediaman Da'itersebut. Aspek efesien dan efektfitas kegiatan dakwah tentunya sangat berpeluang dalam tindakan ini.

Lebih jauh dari itu, penulis memahami bahwa Majelis Dakwah Islamiyah (MDI) Kota Pekanbaru benar-benar fokus dalam kesuksesan kegiatan dakwah melalui khutbah Jum'at ini. Majelis Dakwah Islamiyah (MDI) Kota Pekanbaru yang dipercayai oleh beberapa masjid selalu memberikan nilai ekstra demi terjaminnya kualitas Da'i yang akan terjun ke setiap Masjid tersebut. Para calon khatib diberikan formulasi tambahan setiap pagi Jum'at sebelum mereka turun ke Masjid-Masjid yang telah ditentukan untuk melaksanakan khutbah Jum'at. Majelis Dakwah Islamiyah (MDI) Kota Pekanbaru tidak ingin "bermain" dalam tugas ini, penulis berasumsi bahwa hal tersebut sebagai bentuk tanggung jawab Majelis Dakwah Islamiyah (MDI) Kota Pekanbaru dalam mengemban amanah dakwah sebagai penerus misi Rasulullah SAW. Tidak hanya memperioritaskan kebutuhan umat yang beragam Majelis Dakwah Islamiyah (MDI) Kota Pekanbaru juga menitikberatkan sepak terjang mereka dalam mewujudkan misi pembangunan Kota Pekanbaru sebagai Kota yang madani. Hal ini terlihat jelas dari materi-materi khutbah yang disusun oleh pengurus Majelis Dakwah Islamiyah (MDI) Kota Pekanbaru. Mereka acapkali melakukan koordinasi dengan pihak Pemerintah Kota guna melihat apa-apa saja yang perlu dibenahi dalam kancah masyarakat Kota Pekanbaru sendiri yang nantinya akan diselaraskan dengan pesan dakwah yang sesuai.

e. Dakwah melalui Majelis Taklim Kegiatan dakwah dapat dilakukan dalam format yang bervariasi, salah satu contohnya dalam sebuah forum pengajian Majelis Taklim. Majelis Dakwah Islamiyah (MDI) Kota Pekanbaru juga meletakkan titik berat dalam hal ini dan menjadikan peluang yang ada ini sebagai salah satu kompas misi dakwah.Keseriusan Majelis Dakwah Islamiyah (MDI) Kota Pekanbaru dalam melaksanakan dakwah melalui Majelis Taklim ini terlihat dari upaya mereka yang sangat memperioritaskan Da'i-Da'i dengan syarat khusus untuk kemudian menjadi narasumber dalam pengajian Majelis Taklim. Penulis beranggapan bahwa kerjasama yang dilakukan antar pihak Majelis Dakwah Islamiyah (MDI) Kota Pekanbaru dengan beberapa Majelis Taklim adalah bentuk kerja sama dalam hal penegakkan amar ma'ruf nahi munkar. Majelis Dakwah Islamiyah (MDI) Kota Pekanbaru dalam hal ini pun tidak terlalu mengedepankan ego organisasi dalam mekanisme pelaksanaannya. Majelis Dakwah Islamiyah (MDI) Kota Pekanbaru memberikan kesempatan kepada setiap Majelis Taklim untuk menentukan kapan jadwal dan apa materi pengajiannya.Langkah selanjutnya 
Majelis Dakwah Islamiyah (MDI) Kota Pekanbaru akan mencari dan menentukan siapa Da'i yang sesuai untuk Majelis Taklim tersebut.

Dengan mempertimbangkan beberapa elemen dasar, mulai dari kemampuan (skill) Da'i, keilmuannya, pengalamannya sampai kepada kharismanya sebagai juru dakwah, Majelis Dakwah Islamiyah (MDI) Kota Pekanbaru kemudian membuat keputusan siapa yang sesuai untuk mengisi pengajian di suatu Majelis Taklim. Langkah pertimbangan ini penulis pahami sebagai bentuk kegiatan dakwah yang terorganisir namun tanpa ikatan, akan tetapi sangat berpotensi untuk kesuksesan misi dakwah yang saat ini sedang diemban sebagai penerus juang Rasulullah SAW.

\section{Model Komunikasi Dakwah Modern}

Model komunikasi dakwah yang dilakukan oleh Majelis Dakwah Islamiyah (MDI) Kota Pekanbaru dalam wajah modern telah teraplikasikan dalam berbagai praktek dakwah mereka.Terealisasikannya model komunikasi dakwah ini juga sebagai wujud dakwah MDI Kota Pekanbaru yang inovatif dan selalu beradaptasi dengan keadaan serta perkembangan zaman. Model dakwah modern yang telah dilakukan diantaranya:

\section{a. Dakwah melalui Televisi}

Dalam pelaksanaan dakwah melalui Televisi ini, kegiatan dakwah Majelis Dakwah Islamiyah (MDI) Kota Pekanbaru dapat dikatakan sebagai kegiatan diluar program pokok namun tetap mendapat fokus yang besar. Hal ini penulis pahami karena Majelis Dakwah Islamiyah (MDI) Kota Pekanbaru secara tertulis tidak memiliki MoU dengan pihak Stasiun Televisi manapun. Akan tetapi Majelis Dakwah Islamiyah (MDI) Kota Pekanbaru juga tidak melarang para
Da'i nya yang memenuhi undangan dari beberapa Stasiun Televisi swasta untuk memberikan nasehat kebaikan mereka sesuai permintaan.

Majelis Dakwah Islamiyah (MDI) Kota Pekanbaru secara tidak langsung juga mendukung keberlangsungan kegiatan dakwah ini. Dengan harapan agar adanya beberapa Da'i Majelis Dakwah Islamiyah (MDI) Kota Pekanbaru di beberapa stasiun televisi dapat membuat para Da'i lebih terlatih dan berpengalaman serta dapat menjadikan jama'ah lebih mengenal sosok-sosok Da'i Majelis Dakwah Islamiyah (MDI) Kota Pekanbaru.

Penunjang keberhasilan kegiatan dakwah tidak terlepas dari keikhlasan para jama'ah menerima dan mendengarkan siapa yang menyampaikan dakwah tersebut. Terkait hal ini Majelis Dakwah Islamiyah (MDI) Kota Pekanbaru telah melakukan satu langkah yang baik sebagai salah satu asset penunjang kesuksesan dakwah Majelis Dakwah Islamiyah (MDI) Kota Pekanbaru. Penulis lebih ingin melihat kepada sisi positif yang jauh lebih banyak dari pada beberapa sisi negatif dari kegiatan dakwah melalui Televisi ini.Oleh karena itu, penulis secara peribadi juga sangat mengapresiasi kegiatan dakwah melalui Televisi ini.

\section{b. Dakwah melalui Radio}

Berkenaan dengan dakwah melalui Radio penulis memiliki asumsi bahwa Majelis Dakwah Islamiyah (MDI) Kota Pekanbaru mempunyai sebuah prioritas penting dalam pelaksanaannya. Awalnya Majelis Dakwah Islamiyah (MDI) Kota Pekanbaru melakukan kegiatan dakwah ini melalui jalinan hubungan kerja sama dengan pihak Radio milik IKMI (Ikatan Masjid Indonesia) Kota Pekanbaru. Selanjutnya, dikarenakan beberapa hal maka Majelis Dakwah Islamiyah (MDI) Kota Pekanbaru terpaksa menghentikan kerja sama ini 
karena prioritas lain. Akan tetapi tidak lama berselang Majelis Dakwah Islamiyah (MDI) Kota Pekanbaru secara perlahan namun pasti mulai membangun Stasiun Radio sendiri dalam frekuensi 99,9 FM. Pembangunan gedung Stasiun Radio ini membuktikan bahwa pengurus Majelis Dakwah Islamiyah (MDI) Kota Pekanbaru telah mulai memahami betapa besarnya peluang keberhasilan dakwah melalui Radio saat ini.

Sesuai dengan uraian di atas penulis juga memahami bahwa apa yang dilakukan oleh Majelis Dakwah Islamiyah (MDI) Kota Pekanbaru ternyata sesuai dengan tujuan pengembangan dakwah mereka secara umum. Saat memiliki Stasiun Radio sendiri maka Majelis Dakwah Islamiyah (MDI) Kota Pekanbaru dapat lebih memfokuskan materi dakwah yang akan disampaikan dan dapat dengan mudah melatih Da'i-Da'i muda (junior) untuk lebih memahami dakwah melalui Radio. Ini merupakan langkah besar tentunya jika semua perencanaan yang dimaksud dapat terealisasikan pada praktek dakwahnya. Tidak ada jaminan pasti bahwa dakwah melalui Radio akan memiliki potensi utama dalam menunjang keberhasilan dakwah, akan tetapi hal ini akan dapat men-dongkrak pilar-pilar dakwah lainnya dalam program dakwah Majelis Dakwah Islamiyah (MDI) Kota Pekanbaru.

\section{c. Dakwah melalui Internet}

Kontribusi dakwah melalui internet di zaman informasi ini sangat berpeluang dalam upaya amar ma'ruf nahi munka. Internet sudah menjadi kebutuhan primer bagi masyarakat untuk mengetahui sesuatu tidak terkecuali dakwah Islam. Tidak mustahil jika media internet ini sungguh-sungguh dilakukan untuk berdakwah akan memberikan dampak positif yang besar dalam kehidupan masyarakat.
Dari penjelasan di atas, jika Majelis Dakwah Islamiyah (MDI) Kota Pekanbaru melakukan dakwah melalui internet perkiraan positif akan berhasil membius masyarakat untuk menerima dakwah yang dilakukan tersebut. Jika di titikberatkan dan di samaratakan dengan kegiatan-kegiatan yang lain. Kegiatan dakwah melalui internet bisa dilakukan oleh Majelis Dakwah Islamiyah (MDI) Kota Pekanbaru dengan cara membuat satu tim IT pengelola website atau situs organisasi Majelis Dakwah Islamiyah (MDI) Kota Pekanbaru. Jika tim IT sudah ada pengurus tidak perlu terlalu mendalam memikirkan tentang internet tersebut karena sudah ada pelaksana khusus yang diamanahkan. Dengan demikian kontribusi Majelis Dakwah Islamiyah (MDI) Kota Pekanbaru dalam dakwah melalui internet sangat berperan.

Lebih tegasnya, jika muatan dakwah melalui internet tersebut diisi oleh karya-karya Da'i Majelis Dakwah Islamiyah (MDI) Kota Pekanbaru itu sendiri, maka dapat dipastikan besar minat pengunjung untuk melihat dan membaca karya tersebut. Mengingat bahwa Da'i-Da'i Majelis Dakwah Islamiyah (MDI) Kota Pekanbaru ratarata menjadi public figurekhususnya bagi masyarakat Kota Pekanbaru dan dakwah bil lisan nya di gemari oleh jama'ah. Sudah tentu membuat penasaran para penggemar jika tidak melihat karyanya di internet.

\section{d. Dakwah melalui Media Cetak}

Peluang dakwah melalui Media Cetak sudah tidak diragukan lagi. Mulai dari Koran, Majalah, Buletin, Tabloid dan sebagainya merupakan perangkat tulisan yang sangat dekat dengan masyarakat. Tidak khayal jika kegiatan dakwah melalui Media Cetak akan dapat menjadi salah satu gerakan dakwah modern yang sangat baik dilakukan saat ini. Pemanfaatan terhadap peluang dakwah yang ada tersebut telah dilakukan oleh Majelis 
Dakwah Islamiyah (MDI) Kota Pekanbaru. Hal tersebut terlihat dari kegiatan dakwah mereka yang dulunya dirangkum dalam beberapa bentuk tulisan yang kemudian dimuat pada beberapa Media Cetak. Bahkan Majelis Dakwah Islamiyah (MDI) Kota Pekanbaru mempunyai Buletin Dakwah tersendiri yang diproduksi secara terprogram dengan maksud agar bisa disebar kepada masyarakat umum. Akan tetapi, hal ini tidak berlangsung dalam selang waktu yang disebabkan beberapa persoalan mendasar maka kegiatan dakwah melalui Buletin Dakwah ini secara terpaksa harus difakumkan untuk sementara waktu sampai batas waktu yang tidak ditentukan.

Dalam pemahaman penulis, terhentinya kegiatan dakwah melalui Buletin Dakwah sebagai salah satu bentuk gerakan dakwah melalui Media Cetak bukan hanya sekedar persoalan kesibukan pengurus dalam tubuh Majelis Dakwah Islamiyah (MDI) Kota Pekanbaru itu sendiri. Lebih jauh dari itu, kurangnya konsistensi dan titik fokus pada kegiatan dakwah melalui Media Cetak juga membuat hambatan itu semakin membesar. Kendala yang dihadapi adalah karena beberapa pengurus inti Majelis Dakwah Islamiyah (MDI) Kota Pekanbaru yang tidak mempunyai cukup waktu untuk mengurus program Buletin Dakwah ini.

Jika ditelusuri lebih lanjut, Majelis Dakwah Islamiyah (MDI) Kota Pekanbaru masih tetap dapat melaksanakan kegiatan dakwah ini bila mereka benar-benar ingin melaksanakannya. Salah satu alternatifnya dengan membentuk satu tim khusus yang membidangi persoalan Buletin Dakwah ini. Dengan demikian, pengurus inti dan seluruh anggota lainnya tidak perlu terlalu memikirkan proseduritas produksi akan tetapi hanya fokus pada gubahan tulisan mereka untuk kemudian dimuat dan disebarkan kepada khalayak ramai. Penulis juga memiliki asumsi dari sudut pandang lain, bahwa kegiatan dakwah melalui Media Cetak ini harus mendapatkan asupan dana tersendiri dengan maksud agar proses produksi yang diharapkan baik akan dapat terlakana. Majelis Dakwah Islamiyah (MDI) Kota Pekanbaru dengan segala keahlian pengurus intinya dan semua anggotanya pasti akan mampu untuk melaksanakan kegiatan dakwah ini jika ingin terus berlanjut ke depannya sebagai salah satu gerakan dakwah dalam mengemban misi dakwah.

\section{KESIMPULAN}

Setelah disajikan dan dianalisis, dapat disimpulkan bahwa model komunikasi dakwah Majelis Dakwah Islamiyah (MDI) Kota Pekanbaru dilakukan dalam dua bentuk yaitu model komunikasi dakwah tradisional dan Modern. Model komunikasi dakwah tradisional yang dilakukan dalam bentuk dakwah Halaqah, dakwah Muhasabah, dakwah khutbah Jum'at, dakwah diskusi ilmiah dan seminar keagamaan dan dakwah Majelis Taklim yang dilakukan untuk memenuhi permintaan dari jama'ah.

Selanjutnya model komunikasi dakwah modern yang secara garis besar sama dengan dakwah berbasis teknologi. Dakwah melalui Televisi, dakwah melalui Radio, dakwah melalui internet. Pada akhirnya, model komunikasi dakwah baik dalam bentuk tradisional maupun modern telah terlaksana dengan baik walau terdapat hambatan dan rintangan.

\section{BIBLIOGRAFI}

Arifin, Anwar, Dakwah Kontemporer : Sebuah Studi Komunikasi, Yogyakarta: Graha Ilmu, 2011.

Aziz, Moh. Ali. Ilmu Dakwah, Jakarta: Kencana, 2008.

Azra, Azyumardi.Menuju Masyarakat Madani: Gagasan, Fakta, dan Tantangan, Bandung: Rosdakarya, 2000. 
Hartono, Toni Hartono dkk. Komunikasi

Dakwah, Pekanbaru: Yayasan Pusaka

Riau, 2011.

Ilaihi, Wahyu. Komunikasi Dakwah, Bandung: Remaja Rosdakarya, 2010.

Ma'arif, Bambang S. dkk.Model Komunikasi Dakwah di Perkotaan (Pendekatan Bil-Hal). Bandung: Universitas Islam Bandung dan Universitas Pendidikan Indonesia, 2012.

Maarif, Bambang S. Komunikasi Dakwah; Paradigma Untuk Aksi.Bandung: Simbiosa Rekatama Media, 2010.

Muhyiddin, Asep dan Agus Ahmad Safei.Metode Pengembangan Dakwah,Bandung: Pustaka Setia, 2002.

Rohman, Abd, Komunikasi dalam AlQur'an ( Realisasi Ilahiyah dan Insaniah ). Malang: UIN- Malang Press, 2007.

Tasmara, Toto. Komunikasi Dakwah. Cet2. Jakarta: Gaya Meda Pratama, 1997.

Tim Penyusun Fakultas Dakwah dan Komunikasi Universitas Islam Negeri Sultan Syarif Kasim Riau-Pekanbaru, 2010.

Zaidallah, Alwisral Imam.Strategi Dakwah dalam membentuk Da'i dan Khotib Professional, Jakarta: Kalam Mulia, 2005.

Website

http://www.islamcendikia.com/204/01/radi o-sebagai-media-dakwah.html? $\mathrm{m}=1$ http://fenditungkal.blogspot.com/2009/11/ dakwah-islam-melalui-radio.html 